\title{
Oral Communication in ESL Through Improvisations, Playwriting And Rehearsals
}

\author{
Chamkaur Gill \\ Faculty of Humanities \& Social Sciences \\ Bond University, Gold Coast \\ Queensland 4229, Australia \\ E-mail: cgill@bond.edu.au
}

Doi:10.7575/aiac.alls.v.4n.1p.34

Received: 04/12/2012

URL: http://dx.doi.org/10.7575/aiac.alls.v.4n.1p.34

Accepted: 03/01/2013

\begin{abstract}
The application of drama strategies which focus more on meaning than on form can provide an impetus for ESL learners to be more confident about speaking, thereby increasing the quantity of their spoken English. This paper discusses existing research and the author's own experiences in an attempt to highlight the positive effects of improvisations, playwriting and rehearsals on the oral output of learners in relation to communicative English.
\end{abstract}

Keywords: ESL, drama, improvisations, playwriting, rehearsals

\section{Introduction}

Speaking is more than just audible linguistic items emanating from people. Basically, it is the oral production of recognisable words put together meaningfully in the process of human communication. It functions as a tool that helps us to define our identities as we interact and network, for personal gain, with the world around us. From the Englishlanguage perspective, native speakers are normally seen as doing all this with ease, but the picture changes when learners of that language are involved. Many ESL learners are constantly hindered by limited fluency arising from insufficient knowledge, control and speed of access in relation to the target language (de Jong \& Perfetti, 2011) comprehensibility and intelligibility issues (Derwing \& Munro, 1997), and foreign-accented speech (Munro \& Derwing, 1995). By virtue of their desire to be comprehensible and intelligible, learners can become fluent in English (Davies, 1990) but, unfortunately, oral fluency is not given attention in L2 classrooms, according to Rossiter, Derwing, Manimtim, and Thomson (2010). Drama-based activities like improvisations, playwriting, and rehearsals can help by providing opportunities for autonomous (teacher-free) use of spontaneous spoken language in an informal environment that encourages individuality. In the long run, fluency and clarity of speech could eventuate, even if the language is not structurally accurate. Progressively expanded speech production over time means ongoing practice, and practice makes perfect.

\section{Drama in ESL learning}

The effectiveness of drama in the oral skills development of language learners (Ashton-Hay, 2005; Ballantyne, Bain, \& Packer, 1997; Di Pietro, 1987; Gill, 2008; Miccoli, 2003) arises, basically, out of its experiential learning characteristics (Dodson, 2000; Gassin, 1990; Knutson, 2003). It helps break the impasse created by the lack of motivation, the fear of rejection, low self-esteem, and absence of spontaneity (Stern, 1980). Students from Asia are brought up on a diet of teacher-controlled education (Klinger, 2000; Wong, 2004) which is a characteristic trait of relational, collectivist culture (Goh, 1996) that presumes respect for those viewed as superiors. They generally exhibit characteristics like limited kinesics and excessive deference that, in addition to their lack of participation, can impede foreign-language learning in conventional language classes (Gill, 2008). Such students generally look to the authority of the teacher for input and prompting (Erbaugh, 1990; Kim, 2004; Klinger, 2000; Rao, 2001) rather than initiate discussion themselves. They often display anxiety when asked to provide impromptu oral responses to questions by teachers. This anxiety increases when teachers constantly correct errors in pronunciation, point out problems with intonation patterns, and request clearer articulation. Besides the drop in confidence levels if they are regularly interrupted while speaking, there is the element of embarrassment felt by learners at this perceived airing of their deficiencies. In the words of Gilbert (2005), "A few humiliating experiences ... may make learners so discouraged that they give up trying" (p. viii). Fear of failure and a subsequent loss of face can hinder their speech production. "Anxious students ... will not learn as quickly as relaxed students" writes MacIntyre (1995, p.96). Drama, by creating a relaxed, communal atmosphere, can help alleviate this anxiety. It has a learner-centred and immersion-based format which is activity-oriented and which can help increase speech output. Genesee (1987) mentions a study that indicates that an activity-based approach produces the same level of speaking and listening skills as a teacher-fronted immersion course, despite the former being only half as long. In essence, drama results in increased oral output because it is kinaesthetic (experiential) and activity-orientated and therefore more stimulating than non-drama-based teaching methodology (Gill, 2013). However, despite evidence that 
drama can be an effective educational strategy for Asians (for example, Gaudart, 1990; Stinson \& Freebody, 2006a, 2006b), it is still largely marginalised in Asia and elsewhere, perhaps because it is not viewed as representing formal education. If given due recognition, it can play a major role in enhancing Asian ESL learners' speaking skills.

Teachers have to arouse interest in their learners by being interesting themselves. Some of the ways they can make their lessons interesting are by (i) being creative and not afraid of experimenting, while displaying sensitivity; (ii) dramatising academic and everyday issues by role-modelling them with their students; (iii) creating a relaxed, student-centred atmosphere; (iv) displaying infectious enthusiasm (Gill, 2008). The actor in each teacher must take centre-stage for successful teaching to develop. Good teaching, according to Gail Godwin (1974), in her novel "The odd woman", is three-fourths theatre. Good teachers are animated and energetic and make their learners like them. It is generally observed that such teachers make their students enjoy the subjects they are teaching. Lepper and Cordova (1992) believe that enjoyable learning translates, for low-motivated learners, into greater interest in the subject matter being studied, greater confidence, and improved learning. There is a strong likelihood that the learners will do better in that subject than one taught by a boring teacher, as evidenced by the experience of Maurer (1997), who found that his Spanish outshone his German because his Spanish teacher was more effective than his German one. Felder (1995) feels that language lessons "in which all students are relegated to passive roles, listening to and observing the instructor and taking notes, do little to promote learning" (p. 24) and proposes that mini-dramas and dialogue enactments be introduced to create a more receptive atmosphere in class. Instead of sitting in neat rows facing their instructor, they are involved in interactive verbal and non-verbal language, with the overall learning environment transformed into one that excites and motivates. The value of motivating instructional materials and instructors is a crucial factor in learning (Dörnyei, 1994; Small, Dodge, \& Jiang, 1996). Barkhuizen (1998) points out that classroom activities associated with perceptions of enjoyment create attitudes that result in heightened motivation and receptivity.

Unlike formal language instruction, drama-based learning is communicative in nature. Communicative activities promote subconscious learning because learners focus on the message rather than the code (Stern, 1992). By extension, this could be taken to mean that when they talk freely, without being overly concerned about the constraints of linguistic accuracy and necessity for clarity of speech (pronunciation and articulation), they focus more on what they are saying (message) than the means by which it is said (code). Besides, they soon become aware of the make-believe nature of drama. It gives them 'masks' which 'hide' their real identities. Unnerving situations become less so under the cover of fiction (Brash \& Warnecke, 2009). This can go some way towards helping them shed their inhibitions. Hudson and Bruckman (2002) suggest that disinhibition helps improve language learning. Unsuppressed and active participation in collaborative improvisations, playwriting and rehearsals can give rise to wide- ranging oral production, thereby creating a fertile learning environment.

Briefly put, ESL learners' speech has been observed to benefit from drama as follows: (a) they are more motivated to speak due to the creation of an informal, risk-free environment; (b) their participation increases because of expanded opportunities arising from the materials and student-centredness; (3) their experimentation and risk-taking with English increases (Ballantyne et al., 1997; Gill, 2008).

\section{Improvisations}

Improvisations require participants to use relevant linguistic and non-linguistic resources they possess in specially created situations wherein immediate responses to unpredictable stimuli have to be produced organically. It hinges on the production of spontaneous, unrehearsed speech specific to the scenario being enacted. In other words, there is little or no time to prepare and participants have to think on their feet. For ESL learners, this can be quite a challenge, given their limitations in English. Oftentimes, their affective filters go up and the shutters come down. However, if they are encouraged to speak in an unrestrained manner without fear of public attention being brought to bear on their speech errors, there is " $\ldots$ a higher likelihood of successful communication, which in turn makes it easier for them to take further risks and speak even more" (Klinger, 2000, p.13). It is a way of challenging learners to use their knowledge of English extemporaneously, however incomplete it may be. They get much more practice in speaking in English, even if there are glaring structural and pronunciation errors in their speech, than they would with traditional, lockstep methodology.

Maurer (1997) refers to improvisation as 'the fifth skill' (after reading, speaking, listening, and writing); it tests what learners know of the target language without any assistance from the teacher. According to Reeve, Bolt, and Cai (1999), when students have the autonomy to pick and choose what to say and how to say it, there is greater internalization of, and motivation for, learning. Walsh (2002) suggests that ESL teachers should promote unobstructed learner-talk as often as possible. "Frequent communicative output produces speech acquisition far more readily than formal accurate output", states Kagan (1995, p. 2).

Unlike teacher-fronted instruction, student-centred improvisations have a sense of novelty. Scientific research indicates that the novelty associated with seeing unfamiliar images promotes learning. In a study done at the University of Magdeburg, Germany, subjects exposed to unfamiliar images exhibited greater activity in a region of the brain responsible for motivation than subjects experiencing the familiar (Bunzeck \& Düzel, 2006). The novelty is not just in the newness of the activity but also in its inherent unpredictability. Something that is unpredictable often results in a heightened sense of excitement, enjoyment and motivation (Maley \& Duff, 1982). There is an air of expectancy that, in turn, causes us to pay attention to what is coming next. When we are focussed and motivated in this manner, learning becomes enjoyable and we "achieve higher levels of cognition, make connections, and experience "aha" moments" (Willis, 2007, p. 1). There is a greater volume of spoken English produced through the interactional "language of 
discourse, transaction, negotiation, explanation and inquiry" (Jones, 1982, p. 7) as the participants "suggest, infer, qualify, hypothesize, generalize, or disagree" (Long \& Porter, 1985, p. 209). Improvisations have a positive effect on oral proficiency, as Liu (2006) found in a study on the acquisition of oral English of 16-year-old Taiwanese students.

Another advantage to be gained from allowing participants to create unhampered, spontaneous dialogue is the opportunities created for the teacher to observe and record speech errors and deal with them at a later point in time, similar to what happens in Strategic Interaction (Di Pietro, 1987). I have found that my Asian and Middle-eastern students appreciate such a strategy, especially if they can have their errors discussed in one-on-one meetings with me after a speaking activity. The feedback that they ask for and get is generally useful for future improvisations and, indeed, in their day-to-day use of English inside and outside the classroom.

One largely untapped improvisation technique in drama-for-ESL is playback theatre. This is a form of interaction in which actors enact personal experiences of individuals as soon as they are recounted. Normally associated with psychodrama and dramaturgy, it can effectively be employed in oral-language learning because it involves, among other things, "active listening ... a variety of modes of expression (body, voice, etc.), learning of appropriate verbal and nonverbal interactive response ... learning as a transformative process" (Feldhendler, 2007, p. 4).

Improvisations can briefly be summed up as whole-person experiences, their holistic nature arising from a simultaneous activation of learners' cognition, physicality and feelings as they deliver unrehearsed, interactive speech spontaneously. Compared to traditional language-teaching methodology, such experiences result in greater oral output.

\section{Playwriting}

Playwriting is a collaborative activity that is experiential and constructivist in nature. According to Knutson (2003), "Experiential learning in the ESL classroom builds on the principle that language-learning is facilitated when students are cooperatively involved in working on a project or task" (p. 56). It is a form of meaningful learning that, according to Kaufman (2004), provides "opportunities for learners to engage in hands-on, minds-on manipulation of raw data in quest of identifying new and increasingly complex patterns, acquisition of novel concepts and construction of new understandings" (p 305).

The raw data that I supply my students, who are divided into groups of various language backgrounds to ensure that they have no recourse to their mother tongues, is in the form of the bare bones of a play-script, with each group getting a different script. Different language groups simply means that there is more talking-time in English. An example of the types of scripts I prepare for the playwriting activity is given below (Figure 1).

Creating a dialogue

Create a dialogue using the information below and then act it out with your partners. Give the characters suitable names where necessary.

(Two friends meet and one of them asks the other about a book he/she had borrowed from him/her)

A: Wants to know when the book will be returned.

B: Embarrassed. Informs A that book is missing.

A: Upset. Seeks explanation.

B: Gives unusual reason.

A: Refuses to believe B.

B: Apologises but insists it is true.

A: Angrily demands that B tell the truth.

B: Gives another outlandish reason.

A: Scolds B for being dishonest. Explains why book is important to him/her.

(Enter $C$ ).

C: Greets A \& B. Wants to know what's going on.

A: Tells C.

C: Surprised. Questions B.

B: Says he/she has to leave. Gives reason.

(Starts to move away)

A: Angrily demands book be returned. Threatens B.

(B exits hurriedly) 
C: Tells A that B sold him/her the book. Unaware that it was A's.

A: Furious. Says that he/she will take action.

C: Says that he/she will help.

(Exit $A \& C)$

Try to expand the dialogue as much as possible. Feel free to include additional details.

C. Gill

Figure 1.Creating a dialogue

Each group's task is to give the skeletal framework complexity and novelty by constructing a short, original play. Such a 'skin-and-bones' script represents a motive for learners to initiate discussion. They have something to start with. The bare structure is the impetus with which to commence oral interaction and, as momentum gathers, to work towards creating a finished product. There is no demand on the students to stick to the outlines, and they are allowed to make changes as they see fit. The main objective behind these frameworks is to trigger discussion between team-members. Individuals enjoy substantial talking-time during such interactions, Davies (1990) believes. The open-ended nature of their collaborative dialogue gives them the opportunity to "reformulate, extend, or reduce one another's attempts at expressing a shared meaning" (Tognini, Philp, \& Oliver, 2010, p. 28.5).

It also gives them autonomy, thereby increasing their motivation to participate (Noels, Clément, \& Pelletier 1999; Reeve et al., 1999). Foster (1998) describes small-group discussions as benefitting students through giving them more L2 speaking time and, because such an activity does not entail giving public presentations in front of class, they avoid negative 'audience effects' (a term introduced in the early $20^{\text {th }}$ century in the field of psychology) like anxiety and selfconsciousness. Compared to the quantity of English in the conventional classroom, cooperative group-work results in more speaking time (Long \& Porter, 1985) which, in turn, generates more spoken language (Kagan, 1995). Learners in activity-based projects have greater opportunities "to experience a much wider range of speech events and to use a much wider range of speech acts than is possible in conventional medium-oriented classes" (Genesee, 1987, p. 74).

The process of collaborative writing in my class takes about 4 hours per week, for 5 weeks. Once done, the students rehearse their plays for around 3 weeks and then stage them. Elgar (2002) sees such a process of discussing, writing and reading the script right through to presenting it as using and learning English in a well-rounded fashion. This is particularly useful for students from countries like China, Japan and Korea who undertake studies in English-speaking locations overseas but have had limited exposure to oral English in their home countries (Kim, 2004; Klinger, 2000; Sawir, 2005). In collaborative activities like playwriting, they see the need to use English in discussions because they are aware that the success or failure of their project depends on oral communication with partners whose first languages are different to theirs. The groups comprise learners of different levels of oral English. It has been found that struggling learners benefit from the presence of more capable students in their groups. The latter serve as scaffolds, or assistance frameworks "providing guided support to their peers during collaborative L2 interactions" (Donato, 1994, p. 51). Occasionally, there are native-speakers or those with native-like abilities in my class. I give them the tasks of surrogacyteaching and language role-modelling. Their presence not only creates the opportunity for scaffolding but also brings into play the zone of proximal development or ZPD that, like scaffolding, is a Vygotskian concept (e.g. McCarthy \& O'Keefe, 2004). ZPD refers to a learner's current level of proficiency and what he or she can learn through interacting with more capable peers, with the 'expert' initially directing the 'novice's' performance and the novice eventually appropriating control over his or her own performance (Aljaafreh \& Lantolf, 1994) with a clear awareness of the functions of spoken language. Richards (2008) categorises the functions of speaking as interactional (e.g. conversation), transactional (e.g. purchasing, negotiating), and performance (e.g. presenting). In other words, the language that they produce is not restricted to set patterns dictated by textbooks. Rather, it is influenced by the need to communicate ideas and is therefore more like the language of daily interaction.

Group playwriting allows for extensive learner-talk which is generally comprehensible to all, fosters balanced participation and, because it is student-centred, instils a sense of motivation in the students, thereby fitting the description of a successful speaking activity, as defined by Ur (1996).

\section{Rehearsals}

Smith (1984) believes that negative experiences like embarrassment, anxiety and loss of confidence are less likely to occur during drama rehearsals. Just as actors in a play generally accept their director's interventions during rehearsals, language-learners participating in rehearsals tend to feel less self-conscious whenever the teacher interrupts, possibly because they feel that they are a part of a formal project being developed and perfected.

Besides the psychological dimension, rehearsals can also help increase learners' linguistic competence. Rehearsals for play-productions comprising set play-scripts naturally involve line-memorisation, and by constantly repeating their lines at rehearsals, learners internalise the structures and are able to reproduce them automatically when required. As Tognini et al. (2010) put it, "fluency develops as language knowledge becomes more automatised" (p. 28.3). Smith (1984) also suggests that rehearsals are better than free conversation as a way of identifying learners' errors (like omitted articles 
and the 'to be' verb-forms) because of the play-script, while O'Gara (2008) states that drama impacts positively on the comprehension and use of verb tenses by children.

Rehearsals can also help improve learners' pronunciation, articulation and prosody. The pre-determined, finite language items in a play-script can be used to guide them in a more focussed and organised manner compared to random, hit-ormiss attempts at identifying errors from spontaneous language production within a restricted time-frame. Dodson (2000) believes that play-reading (an initial component of the rehearsal undertaking) is "excellent for improving pronunciation and intonation" (p. 10). 'Use maketh mastery', goes an Urdu idiom, and by using correct forms regularly during rehearsals, learners can develop target-language-like speech rhythms over time (Gassin, 1990). Besides that, they can also learn how to use their vocal apparatus, i.e. lips, teeth, tongue and throat in new ways, to match the requirements of the target language (Dickson, 1989). In addition, breathing, articulation, pacing, and rhythm exercises during rehearsals can be of use in developing more effective listening and speaking skills (Dunkel, 1986, Smith, 1984).

It is generally accepted that, ideally, actors have to reproduce lines verbatim in order to perform a play successfully; therefore, the process of casting lines to memory inevitably involves rote learning. Rote learning is much maligned not only because of its decidedly Skinnerian behaviouristic leanings but also because it is based on the premise that making sense of what is being memorised is less crucial than just memorising it. Smith (2005) opines that "Rote learning does not invite students to understand connections" (p. 254) but this is true only if the instructor does not step in to help the learners make connections. A teacher conducting rehearsals can help his or her learners understand what they are memorising by clarifying the message at the word, phrase, sentence and script levels of the dialogue in a play. Such a practice makes a rehearsal more than just a mechanised production of memorised speech, especially when combined with ensuring that the learners also know and understand how and why the lines have to be delivered with specific emotions, at a certain pace, and with the right intonation patterns, among other things. Moreover, a teacher need not be the controlling force throughout the rehearsal process. From a communicative-speaking perspective, it is far more effective, once the initial preparations have been completed, for the teacher to let the students conduct their own rehearsals. Here, as with playwriting, collaboration is the key as the students interact with each other during the stages leading up to their final performance. Scaffolding and the ZPD are often found in abundance during this time.

In addition, regular practice with a set text can help learners develop a sense of familiarity with it. Familiarity puts them in a comfort-zone, thereby reducing self-doubt, anxiety and self-consciousness (Dodson, 2002; Dougill, 1987). Rehearsals assist learners in overcoming short-term memory constraints and committing learning to long-term memory. Howe (1998) mentions studies that point to the benefits of rehearsals and repetitions by children. Learners memorising a script remember more of the text with long-term rehearsals. While it is unlikely that all the lines will remain in the performers' active memories after a period of time following the end of a performance, certain items, particularly those which have left an impression on the learners, can be retrieved. If retrieved on a regular basis, these items might even become a permanent fixture in the speaker's repertoire. Erdman (1991) noticed that children learning Spanish via drama were able to remember their own and also their co-actors' lines some time after a performance. Not only that, they were also able to create new sentences containing different vocabulary by recombining idiomatic parts of their lines, with basically the same syntactic structure. Smith (2005) concedes that rote learning "does provide many learners with a set of tools that may have use over and above their immediate application." (p. 254). Vocabulary, clichés, idioms, phrases, sentences and prosodic features (intonation, stress) memorised from drama texts can be used constructively and meaningfully at later points in time in spontaneous oral interactions. It could be argued that a behaviourist-constructivist blend is in operation here because what has been mechanically memorised eventually leads to cognitive utilisation. de Jong and Perfetti (2011) found that repetitive speech-giving increased fluency and resulted in fewer pauses, with these improvements being transferred to new topics. Learners progress "from very structured activities to partially structured ones and finally to free expression" (Dickson, 1989, p. 302).

Another way rehearsals can help learners is through contextualisation. Language items are less relevant as stand-alone entities than as part of a wider message in human communication. Rehearsals represent the sort of focus on form which is "based on meaningful contexts rather than a predetermined and decontextualized linguistic form" Liu (2002, p.3). Tackling language features like grammar, vocabulary and pronunciation in context rather than in isolation makes for more meaningful and effective learning. Tognini et al. (2010), in discussing peer interaction, believe that "repeated language use provides contextualised practice of language forms" (p. 28.3). Play-scripts contain contextualised language that learners can practise with repeatedly.

Briefly then, although there is less autonomy during rehearsals, learners get to improve their oral output through constant practice of correct linguistic forms and sounds that exist within the context of a play-script.

\section{Conclusion}

One of the most obvious outcomes of drama activities such as improvising, playwriting and rehearsing in EFL classrooms is the increase in the oral output of learners. These three experiential undertakings, when compared with the conventional teacher/textbook-centred methodology, promote less rigid and more open-ended learning. The studentcentred nature of drama makes for a relaxed, enjoyable atmosphere in the learning environment. Many learners find this energising and motivating. Improvisations create situations that require them to say what comes to mind in English, without restrictions on their speech production. The more they enjoy this, the larger the volume of spoken English produced. Playwriting creates opportunities to speak in free-flowing English with peers as they work collaboratively on their project. The presence of scaffolding and the ZPD is a major boon in such an activity. Finally, rehearsals, though different from improvisations and playwriting because of the presence of the teacher as director, allow for contextual 
learning in relation to language-structure and also pronunciation, articulation and prosody. Rehearsals managed by the students themselves represent productive collaborative learning. Collectively, improvisations, playwriting and rehearsals represent endeavours that, if used diligently, can play an important role in heightening learners' use of communicative English.

\section{References}

Aljaafreh, A. \& Lantolf, J. P. (1994). Negative feedback as regulation and second language learning in the zone of proximal development. Modern Language Journal, 78(4), 465-483. http://dx.doi.org/10.1111/j.15404781.1994.tb02064.x

Ashton-Hay, S. (2005). Drama: Engaging all learning styles. In Proceedings $9^{\text {th }}$ International INGED (Turkish English Education Association) Conference, Economics and Technical University, Ankara, Turkey. Retrieved from http://eprints.qut.edu.au/12261/1/12261a.pdf

Ballantyne, R., Bain, J., \& Packer, J. (1997). Reflecting on university teaching: Academics' stories. Canberra: Australian Government Publishing Service.

Barkhuizen, G. P. (1998). Discovering learners' perceptions of ESL classroom teaching/learning activities in a South African context. TESOL Quarterly, 32(1), 85-108. http://www.jstor.org/stable/3587903

Brash, B. \& Warnecke, S. (2009). Shedding the ego: Drama-based role-play and identity in distance language tuition. Language Learning Journal, 37(1), 99-109.

http://dx.doi.org/10.1080/09571730902717661

Bunzeck, N. \& Düzel, E. (2006). Absolute coding of stimulus novelty in the human substantia nigra/VTA. Neuron 51, 369-379.

http://dx.doi.org/10.1016/j.neuron.2006.06.021

Davies, P. (1990). The use of drama in English language teaching. TESL Canada Journal, 8(1), 87-99. Retrieved from http://journals.sfu.ca/tesl/index.php/tesl/article/viewFile/581/412

de Jong, N \& Perfetti, C. A. (2011). Fluency training in the ESL classroom: An experimental study of fluency development and proceduralization. Language Learning, 61(2), 533-568.

http://dx.doi.org/10.1111/j.1467-9922.2010.00620.x

Derwing, T. M. \& Munro, M. J. (1997). Accent, intelligibility and comprehensibility. Studies in Second Language Acquisition, $\quad 19(1), \quad 1-16 . \quad$ Retrieved from www.journals.cambridge.org/action/displayAbstract? fromPage $=$ online $\&$ aid $=36363$

Dickson, P. S. (1989). Acting French: Drama techniques in the second language classroom. The French Review, 63(2), 300-311.

Di Pietro, R. J. (1987). Strategic Interaction: Learning languages through scenarios. Cambridge: Cambridge University Press.

Dodson, S. L. (2000). FAQs: Learning languages through drama. In M. Carpenter (Ed.), Proceedings for the Texas Foreign Language Conference: Texas Papers in Foreign language Education, University of Texas at Austin, 5(1), 129141. Retrieved from http://www.eric.ed.gov/PDFS/ED468313.pdf

Dodson, S. L. (2002). The educational potential of drama for ESL. In G. Bauer (Ed.), Body and language: Intercultural learning through drama, 161-179, Westport, CT: Ablex Publishing. Retrieved from http://www.europeanmediaculture.org/fileadmin/bibliothek/english/dodson_drama/dodson_drama.pdf

Donato, R. (1994). Collective scaffolding in second language learning. In J. Lantolf \& G. Appel (Eds.), Vygotskian approaches to second language research (pp 33-56). Norwood, NJ: Ablex Publishing Corporation.

Dörnyei, Z. (1994). Motivation and motivating in the foreign language classroom. The Modern Language Journal, 78(3), 273-284. Retrieved from http://www.jstor.org/stable/330107

Dougill, J. 1987. Drama activities for language learning. London: Macmillan.

Dunkel, P. (1986). Developing listening fluency in L2: Theoretical principles and pedagogical considerations. The Modern Language Journal, 70(2), 99-106. http://dx.doi.org/10.1111/j.1540-4781.1986.tb05250.x

Elgar, A. G. (2002). Student playwriting for language development. ELT Journal, 56(1), 22-28. Retrieved from http:/eltj.oxfordjournals.org/content/56/1/22.full.pdf

Erbaugh, M. S. (1990). Taking advantage of China's literary tradition in teaching Chinese students. The Modern Language Journal, 74(1), 15-27. http://dx.doi.org/10.1111/j.1540-4781.1990.tb02548.x

Erdman, H. (1991). Conflicts of interest: Bringing drama into the elementary foreign language classroom. Youth Theatre Journal, 5(3), 12-14.

Feldhendler, D. (2007). Playback theatre: A method for intercultural dialogue. Scenario, 2. Retrieved from http://publish.ucc.ie/scenario/2007/02/feldhendler/04/en 
Felder, R. M. (1995). Learning and teaching styles in foreign and second language education. Foreign Language Annals, 28(1), 21-31. Retrieved from http://www4.ncsu.edu/unity/lockers/users/f/felder/public/Papers/FLAnnals.pdf

Foster, P. (1998). A classroom perspective on the negotiation of meaning. Applied linguistics, 19(1), 1-23. Retrieved from http://applij.oxfordjournals.org/content/19/1/1.full.pdf + html

Gaudart, H. (1990). Using drama techniques in language teaching. ERIC Reproduction Services ED 366 197. Retrieved from http://www.eric.ed.gov/PDFS/ED366197.pdf

Gassin, J. (1990). The notion of synchrony in second language learning. In M. Halliday, J. Gibbons \& H. Nicholas (Eds.), Learning, keeping and using languages (pp 433-443). Amsterdam: Newbury House

Genesee, F. (1987). Learning through two languages: Studies of immersion and bilingual education. Cambridge, MA: Newbury House.

Gilbert, J. B. (2005). Clear speech: Pronunciation and listening comprehension in North America. New York, NY: Cambridge University Press.

Gill, C. (2008). Motivating English-language learners through drama techniques. The Journal of INTI International Educational Group, (Special Issue on Teaching and Learning), 43-51.

Gill (2013). Enhancing the English-language oral skills of international students through drama. English Language Teaching, 6(4), 29-41. http://dx.doi.org/doi:10.5539/elt.v6n4p29

Godwin, G. (1974). The odd woman. New York: Random House

Goh, B. C. (1996). Negotiating with the Chinese. Aldershot, Hants: Dartmouth Publishing Company.

Howe, M. J. A. (1998). Principles of abilities and human learning. Hove, East Sussex: Psychology Press.

Hudson, J. M. \& Bruckman, A. (2002). Disinhibition in a CSCL environment. In G. Stahl (Ed.), Proceedings of Computer Support for Collaborative Learning (CSCL), 629-630. Boulder, CO: Routledge.

Jones, K. (1982). Simulations in language teaching. Cambridge: Cambridge University Press.

Kagan, S. (1995). We can talk: Cooperative learning in the elementary ESL classroom. ERIC Digest. Retrieved from http://eric.ed.gov/PDFS/ED382035.pdf

Kaufman, D. (2004). Constructivist issues in language learning and teaching. Annual Review of Applied Linguistics, 24, 303-319. http://dx.doi.org/10.1017/S0267190504000121

Kim, S. J. (2004). Coping with cultural obstacles to speaking English in the Korean secondary school context. Asian EFL Journal, 6(2). Retrieved from

http://www.asian-efl-journal.com/september-04_ksj.php

Klinger, W. (2000). Unrehearsed speaking activities for language learning. Academic reports of the University Center for Intercultural Education, The University of Shiga Prefecture, No. 5 Hikone, Japan. Retrieved from http://www.ice.usp.ac.jp/ wklinger/wk99-Unrehearsed.pdf

Knutson, S. (2003). Experiential learning in second-language classrooms. TESL Canada Journal, 20(2), 52-64. Retrieved from http://www.teslcanadajournal.ca/index.php/tesl/article/viewFile/948/767

Lepper, M. R., \& Cordova, D. I. (1992). A desire to be taught: Instructional consequences of intrinsic motivation. Motivation and Emotion, 16, 187-208. Retrieved from http://www.idemployee.id.tue.nl/g.w.m.rauterberg/lecturenotes/JFS-lecture/lepper-cordova-1992.pdf

Liu, J. (2002). Process drama in second- and foreign-language classrooms. In G. Bräuer (Ed.), Body and language: Intercultural learning through drama, 51-70. London: Ablex.

Liu, W-c. (2006). Memorization and improvisation: A comparison of two strategies in the oral acquisition of English as a second language. (Doctoral dissertation, Australian Catholic University, Australia). Retrieved from www.dlibrary.acu.edu.au/digitaltheses/public/adt-acuvp124.25102006

Long, M. H. \& Porter, P. A. (1985). Group work, interlanguage talk, and second language acquisition. TESOL Quarterly 207-228. Retrieved from

http://course1.winona.edu/hshi/documents/groupwork_interlanguagetalkandl2acquisition.pdf

MacIntyre, P. D. (1995). How does anxiety affect second language learning? A reply to Sparks and Ganschow. The Modern Language Journal, 79(1), 90-99.

Maley, A. \& Duff, A. (1982). Drama techniques in language learning: A resource book on communicative activities for language teachers. Cambridge: Cambridge University Press.

Maurer, J. K. (1997). Presentation, practice, and production in the EFL class. The Language Teacher. Retrieved from http://jalt-publications.org/old_tlt/files/97/sep/maurer.html

McCarthy, M. \& O'Keeffe, A. (2004). Research in the teaching of speaking. Annual Review of Applied Linguistics, 24, 26-43. http://dx.doi.org/10.1017/S0267190504000029

Miccoli, L. (2003). English through drama for oral skills development. ELT Journal, 57(2), 122-129. http://dx.doi.org/doi:10.1093/elt/57.2.122 
Munro, M. J. \& Derwing, T. M. (1995). Processing time, accent and comprehensibility in the perception of native and foreign-accented speech. Language and Speech, 38(3), 289-306. http://dx.doi.org/10.1177/002383099503800305

Noels, K. A., Clément, R., \& Pelletier, L. G. (1999). Perceptions of teachers' communicative style and students' intrinsic and extrinsic motivation. Modern Language Journal, 83, 23-34. Retrieved from http://users.telenet.be/cr32258/teacher\%20styles\%20intrinsic\%20extrinsic\%20student\%20motivation.pdf

O'Gara, P. (2008). To be or have not been: Learning language tenses through drama. Issues in Educational Research, 18(2), 156-166. Retrieved from http://www.iier.org.au/iier18/ogara.html

Rao, Z. (2001). Matching teaching styles with learning styles in East Asian contexts. The Internet TESL Journal, 7(7). Retrieved from

http://iteslj.org/Techniques/Zhenhui-TeachingStyles.html

Reeve, J., Bolt, E., \& Cai, Y. (1999). Autonomy-supportive teachers: How they teach and motivate students. Journal of Educational Psychology, 91(3), 537-548. http://dx.doi.org/10.1037/0022-0663.91.3.537

Richards, J. C. (2008). Teaching listening and speaking: From theory to practice. New York, NY: Cambridge University Press.

Rossiter, M. J., Derwing, T. M., Manimtim, L. G., \& Thomson, R. I. (2010). Oral fluency: The neglected component in the communicative language classroom. The Canadian Modern Language Review, 66(4), 583-606. Retrieved from http://130.102.44.245/journals/canadian_modern_language_review/v066/66.4.rossiter.pdf

Sawir, E. (2005). Language difficulties of international students in Australia: The effects of prior learning experience.

International Educational Journal, 6(5), 567-580. Retrieved from http://ehlt.flinders.edu.au/education/iej/articles/v6n5/Sawir/paper.pdf

Small, R. V., Dodge, B. J., \& Jiang, X. (1996). Dimensions of interest and boredom in instructional situations. Proceedings of Annual Conference of the Association for Educational Communications and Technology, Indianapolis, IN. Retrieved from

http://www.eric.ed.gov/PDFS/ED397840.pdf

Smith, A. (2005). The brain's behind it. Norwalk, CT: Crown House Publishing.

Smith, S. M. (1984). The theatre arts and the teaching of second languages. Reading, MA: Addison-Wesley.

Stern, H. H. (1992). Issues and options in language teaching. Oxford: Oxford University Press.

Stern, S. L. (1980). Drama in second language learning from a psycholinguistic perspective. Language Learning 30(1), $77-100$.

http://dx.doi.org/10.1111/j.1467-1770.1980.tb00152.x

Stinson, M. \& Freebody, K. (2006a). The DOL project: An investigation into the contribution of process drama to improved results in English oral communication. Youth Theatre Journal, 20, 27-41.

Stinson, M. \& Freebody, K. (2006b). Modulating the mosaic: Drama and oral language. In L. A. McCammon \& D. McLauchlan (Eds.), Universal mosaic of drama and theatre: The IDEA04 dialogues (pp. 193-201). Ottawa, Canada: IDEA publications.

Tognini, R., Philp, J., \& Oliver, R. (2010). Rehearsing, conversing, working it out: second language use in peer interaction. Australian Review of Applied Linguistics, 33(3), 28.1-28.25.

Ur, P. (1996). A course in language teaching: Practice and theory. Cambridge: Cambridge University Press.

Walsh, S. (2002). Construction or obstruction: teacher talk and learner involvement in the EFL classroom. Language Teaching Research, 6(1), 3-23.

http://dx.doi.org/10.1191/1362168802lr095oa

Willis, J. (2007). The neuroscience of joyful education. Educational Leadership, 64. Retrieved from http://www.psychologytoday.com/files/attachments/4141/the-neuroscience-joyful-education-judy-willis-md.pdf

Wong, J. K. K. (2004). Are the learning styles of Asian international students culturally or contextually based? International Education Journal, 4(4), 154-166. Retrieved from http://ehlt.flinders.edu.au/education/iej/articles/v4n4/wong/paper.pdf 